\title{
PENGARUH KOMPETENSI DAN INDEPENDENSI PADA KINERJA AUDITOR INTERNAL PEMERINTAH DENGAN ETIKA AUDITOR SEBAGAI VARIABEL MODERASI \\ (STUDI PADA INSPEKTORAT KABUPATEN TEGAL)
}

\author{
Uly Maria Ulfah \& Fitri Lukiastuti \\ Magister Manajemen, STIE Bank BPD Jawa Tengah \\ oelyymu@yahoo.co.id \& fitri111269@stiebankbpdjateng.ac.id
}

\begin{abstract}
ABSTRAK
Auditor internal pemerintah harus mematuhi peraturan ketenagakerjaan sebagai Pegawai Negeri dan harus mematuhi kode etik APIP dan standar audit APIP yang telah ditetapkan ketika melakukan pembinaan dan pengawasan. Auditor membutuhkan dua hal utama, yaitu kompetensi dan independensi untuk menghasilkan kualitas audit yang tinggi. Penelitian ini bertujuan untuk memberikan bukti empiris tentang pengaruh kompetensi dan independensi terhadap kinerja auditor internal pemerintah, serta peran etika auditor dalam memoderasi pengaruh kompetensi dan indepensi terhadap kinerja auditor internal pemerintah. Populasi dalam penelitian ini adalah seluruh auditor yang bekerja di Inspektorat Kabupaten Tegal yang berjumlah 40 orang. Metode analisis yang digunakan adalah Moderated Regression Analysis. Hasil penelitian membuktikan kompetensi dan independensi auditor berpengaruh positif dan signifikan terhadap kinerja auditor. Hasil lain dari etika auditor menganaletikan hubungan antara kompetensi dan independensi auditor terhadap kinerja auditor.
\end{abstract}

Kata Kunci: Kompetensi, Independensi, Etika, Kinerja Auditor.

\begin{abstract}
Government internal auditors must comply with labor regulations as civil servants and must comply with the APIP code of ethics and APIP audit standards that have been established when conducting guidance and supervision. Auditors need two main things, namely competence and independence to produce high audit quality. This study aims to provide empirical evidence about the influence of competence and independence on the performance of government internal auditors, as well as the role of auditor ethics in moderating the influence of competence and independence on the performance of government internal auditors. The population in this study are all auditors who work in the Tegal District Inspectorate, amounting to 40 people. The analytical method used is Moderated Regression Analysis. The results of the study prove that auditor competence and independence have a positive and significant effect on auditor performance. Other results from auditor ethics analyze the relationship between competency and auditor independence to auditor performance.
\end{abstract}

Keywords: Competence, Independence, Ethics, Auditor Performance. 


\section{Uly Maria Ulfah}

\section{Fitri Lukiastuti}

\section{PENDAHULUAN}

Inspektorat Kabupaten Tegal dibentuk berdasarkan Peraturan Daerah Kabupaten Tegal Nomor 9 Tahun 2008 tentang Pembentukan Organisasi Inspektorat dan Lembaga Teknis Daerah sebagaimana diubah terakhir dengan Peraturan Daerah Kabupaten Tegal Nomor 12 Tahun 2016 Tentang Pembentukan dan Susunan Perangkat Daerah Kabupaten Tegal. Inspektorat berkedudukan sebagai unsur penunjang Pemerintah Daerah di bidang Pengawasan yang dipimpin oleh seorang Inspektur yang berada di bawah dan bertanggung jawab langsung kepada Bupati Tegal melalui Sekretaris Daerah. Inspektorat Kabupaten Tegal mempunyai tugas pokok melakukan pembinaan pengawasan terhadap pelaksanaan urusan pemerintahan di daerah, pelaksanaan pembinaan atas penyelenggaraan pemerintahan desa dan pelaksanaan urusan pemerintahan desa.

Inspektorat Kabupaten Tegal masih terkendala dengan kuantitas dan kualitas aparat pemeriksanya dalam menjalankan tugas pokok tersebut. Hasil Evaluasi atas Penerapan Jabatan Fungsional Auditor (JFA) oleh Pusat Pembinaan JFA Badan Pengawasan Keuangan dan Pembangunan (BPKP) pada Inspektorat Kabupaten Tegal Tahun 2015 menghasilkan kesimpulan bahwa jumlah dan komposisi auditor pada Inspektorat Kabupaten Tegal masih belum ideal untuk melaksanakan pembinaan dan pengawasan sintern Pemerintah Kabupaten secara efektif. Terdapat 9 (sembilan) atau 17\% dari 52 (limapuluh dua) jumlah minimal Pejabat Fungsional Auditor (PFA) Kabupaten Tegal yang harus terisi. Terdapat satu orang Auditor Pelaksana Lanjutan yang harus diberhentikan dari jabatannya karena belum meningkatkan pendidikannya minimal Diploma 3 (D3) atau sederajat sejak yang bersangkutan diangkat ke dalam JFA per 1 April 2005. Pasal 36 ayat (1) dan (2) pada Permen PAN Nomor: PER/220/M.PAN/7/2008 menyebutkan bahwa Auditor dengan usia paling tinggi 40 tahun pada saat peraturan ini ditetapkan, diwajibkan untuk memiliki ijazah paling rendah Diploma 3 (D3) atau yang sederajat, paling lama enam tahun sejak peraturan ini ditetapkan.

Menindaklanjuti rekomendasi Hasil Evaluasi atas Penerapan JFA oleh Pusbin JFA BPKP pada Inspektorat Kabupaten Tegal Tahun 2015, Pemerintah Kabupaten Tegal telah melakukan penjaringan minat Jabatan Fungsional Auditor pada masing-masing SKPD yang dilaksanakan pada awal tahun 2016. Hasil penjaringan tersebut memperoleh penambahan auditor sebanyak 24 (dua puluh empat) orang Sarjana (S1) pada pertengahan 2016 dan 2 (dua) orang D3 diawal tahun 2017. Namun demikian, ternyata penambahan jumlah auditor ini tidak menjadikan capaian kinerja pelaksaan program kerja pengawasan di Inspektorat Kabupaten Tegal menjadi lebih baik di tahun 2016. Laporan Kinerja Instansi Pemerintah (LKjIP) Inspektorat Tahun 2016 menyebutkan bahwa penyelesaian Program Kerja 
Pengawasan Tahunan (PKPT) hanya mencapai 76\%, yang berarti terjadi penurunan dibanding tahun sebelumnya yang mencapai $100 \%$.

Pelaksanaan program kerja pengawasan di Inspektorat Kabupaten Tegal sangat berkaitan dengan independensi dan kompetensi yang dimiliki auditor. Mardiasmo (2005) dalam Salju (2014) menjelaskan bahwa pemeriksaan (audit) merupakan kegiatan yang dilakukan oleh pihak yang memiliki independensi dan memiliki kompetensi profesional untuk memeriksa apakah hasil kinerja pemerintah telah sesuai dengan standar yang ditetapkan. Independensi merupakan salah satu prinsip dasar dalam standar audit (Salju, 2014). Terkait dengan independensi, Aparat Pengawasan Intern Pemerintah (APIP) di Inspektorat Kabupaten Tegal masih menemui banyak kendala di lapangan seperti misalnya kedudukan Inspektorat dalam struktur Organisasi Perangkat Daerah. Inspektorat adalah bagian integral dari Pemerintahan Daerah yang berada dibawah Kepala Daerah, dimana berdasarkan Undang- Undang 23 Tahun 2014 pasal 216 ayat 3, Kepala Daerah melimpahkan sebagian atau seluruh kekuasaannya kepada sekretaris daerah selaku koordinator pengelolaan keuangan daerah. Salah satu tugasnya adalah memberikan persetujuan pengesahan DPA SKPD induk dan perubahan, termasuk didalamnya DPA Inspektorat. Secara implisit, Inspektorat Kabupaten Tegal memiliki "ketergantungan" dalam hal anggaran terhadap Sekretaris Daerah. Di samping itu, Sekretaris Daerah adalah kepala/pimpinan di SKPD Sekretariat Daerah yang merupakan auditi/obyek pemeriksaan Inspektorat.

Kompetensi dan independensi yang dimiliki auditor dalam penerapannya akan terkait dengan etika (Saputra, 2013). Auditor mempunyai kewajiban untuk menjaga standar perilaku etis tertinggi mereka kepada organisasi dimana mereka bernaung, profesi mereka, masyarakat dan diri mereka sendiri. Selain itu, auditor mempunyai tanggung jawab menjadi kompeten serta menjaga integritas dan obyektivitas mereka (Lestari et al., 2017). Berdasarkan perumusan masalah diatas, maka diajukan pertanyaan penelitian sebagai berikut:

a. Apakah kompetensi berpengaruh terhadap kinerja auditor internal pemerintah?

b. Apakah independensi berpengaruh terhadap kinerja auditor internal pemerintah?

C. Apakah etika auditor dapat memoderasi pengaruh indepensi terhadap kinerja auditor internal pemerintah?

d. Apakah etika auditor dapat memoderasi pengaruh kompetensi terhadap kinerja auditor internal pemerintah? 


\section{Uly Maria Ulfah}

\section{Fitri Lukiastuti}

Penelitian ini mempunyai tujuan untuk:

a. Memberikan bukti empiris mengenai pengaruh kompetensi terhadap kinerja auditor internal pemerintah.

b. Memberikan bukti empiris mengenai pengaruh indepensi terhadap kinerja auditor internal pemerintah;

c. Memberikan bukti empiris etika auditor dapat memoderasi pengaruh indepensi terhadap kinerja auditor internal pemerintah

d. Memberikan bukti empiris etika auditor dapat memoderasi pengaruh kompetensi terhadap kinerja auditor internal pemerintah

Berdasarkan kerangka teori dan penelitian terdahulu, maka rumusan hipotesis penelitian ini adalah:

$\mathrm{H}_{1}$ : Kompetensi berpengaruh terhadap kinerja auditor intern pemerintah.

$\mathrm{H}_{2}$ : Etika auditor memoderasi pengaruh kompetensi terhadap kinerja auditor intern pemerintah

$\mathrm{H}_{3}$ : Indepensi berpengaruh terhadap kinerja auditor intern pemerintah

$\mathrm{H}_{4}$ : Etika auditor memoderasi pengaruh independensi terhadap kinerja auditor intern pemerintah

\section{METODE PENELITIAN}

Objek dalam penelitian ini adalah Auditor yang bekerja di Inspektorat Kabupaten Tegal yang terletak di Jl. A. Yani No. 173 Slawi, Kabupaten Tegal. Populasi dalam penelitian ini adalah seluruh auditor yang bekerja di Inspektorat Kabupaten Tegal, sejumlah 40 orang. Teknik Pengambilan sampel menggunakan metode sensus. Sensus adalah teknik penentuan sampel apabila semua anggota populasi digunakan sebagai sampel (Sugiyono, 2012). Hal ini sering dilakukan bila jumlah populasi relatif kecil, kurang dari 30 orang, atau penelitian yang ingin membuat generalisasi dengan kesalahan yang sangat kecil. Penelitian ini menggunakan uji regresi berganda dalam menguji hipotesis satu dan hipotesis tiga, sedangkan hipotesis dua dan empat menggunakan Moderated Regression Analysis atau disingkat MRA untuk menentukan apakah variabel etika auditor merupakan variabel moderasi (Ghozali, 2006). Analisis MRA digunakan untuk melihat apakah ada pengaruh variabel bebas terhadap variabel tak bebas dan untuk melihat apakah dengan diperhatikannya variabel moderasi dalam model dapat meningkatkan pengaruh dari variabel bebas terhadap variabel tak bebas atau malah sebaliknya. 


\section{HASIL DAN PEMBAHASAN}

Berdasarkan hasil perhitungan validitas diperoleh korelasi hitung ( $r$ hitung) pada setiap pertanyaan pada variabel penelitian nilainya lebih besar dari $r_{\text {tabel }}=0,312$ (dengan alpha 5 persen). Nilai terendah adalah pada item pertanyaan keenam variabel independensi (X1.3) yaitu 0,319. Berdasarkan hasil tersebut dapat dikatakan bahwa pertanyaan yang tergabung dalam variabel penelitian adalah valid untuk dijadikan instrumen penelitian. Hasil perhitungan reliabilitas diperoleh nilai alpha cronbach pada setiap variabel penelitian nilainya lebih besar dari $r$ tabel $(0,312)$, dimana nilai terendah adalah pada variabel independensi yaitu 0,788. Hal tersebut menunjukkan bahwa pernyataan yang tergabung dalam instrumen variabel penelitian adalah reliabel untuk dijadikan instrumen dalam penelitian.

Model persamaan regresi yang baik adalah model yang memenuhi persyaratan asumsi klasik, diantaranya adalah data berdistribusi normal, model bebas dari multikolinieritas dan terbebas dari heteroskedasitas. Berdasarkan hasil sebelumnya, terbukti bahwa model yang diajukan dalam penelitian ini telah memenuhi persyaratan asumsi klasik sehingga model dalam penelitian ini sudah baik.

Tabel 1. Ringkasan Hasil Analisis Regresi Linier Berganda Pertama

\begin{tabular}{lccrc}
\hline \multicolumn{1}{c}{ Variabel } & $\begin{array}{l}\text { Koefisien } \\
\text { regresi }\end{array}$ & Standar error & t hitung & Signifikansi \\
& 1,539 & 0,659 & 2,335 & $0,026^{*}$ \\
Kompetensi & 1,326 & 0,546 & 2,430 & $0,021^{*}$ \\
Independensi & 2,859 & 0,868 & 3,294 & $0,002^{* *}$ \\
Etika & $-0,033$ & 0,012 & $-2,671$ & $0,012^{*}$ \\
Kompetensi Etika & $-0,020$ & 0,009 & $-2,141$ & $0,040^{*}$ \\
Independensi Etika & $-116,557$ & 46,923 & $-2,484$ & 0,018 \\
Konstanta & $=0,700$ & & & \\
R Square & $=15,891$ & & \\
F hitung & $=, 000 * *$ & & \\
Probability & & & \\
Keterangan: & & & \\
** Signifikan sampai dengan taraf nyata 1\% & & \\
$*$ Signifikan sampai dengan taraf nyata 5\% & & \\
\hline
\end{tabular}




\section{Uly Maria Ulfah}

\section{Fitri Lukiastuti}

Sesuai dengan hasil regresi di atas, persamaan regresi linier berganda yang dihasilkan adalah: $Y=-116,557+1,539 X_{1}+1,326 X_{2}+2,859 X_{3}-0,033 X 1 . X 3-0,020 \times 1 . X 3+\varepsilon$

Dimana:

$$
\begin{array}{ll}
X_{1} & =\text { Kompetensi } \\
X_{2} & =\text { Independensi } \\
X_{3} & =\text { Etika } \\
X_{1} \cdot X_{3} & =\text { Kompetensi } X \text { Etika } \\
X_{2} \cdot X_{3} & =\text { Indepenedensi } X \text { Etika } \\
\varepsilon & =\text { standar eror hasil perhitungan }
\end{array}
$$

Berdasarkan data pada tabel 1 dan persamaan di atas terlihat ketiga variabel yaitu kompetensi, independensi dan etika auditor memiliki nilai koefisien regresi yang positif dalam model regresi terhadap kinerja auditor. Hal ini berarti:

a. Nilai konstanta yang negatif $(-116,557)$, mengandung arti bahwa kondisi kinerja auditor sebelum adanya variabel bebas (kompetensi, independensi ddan etika) dalam kondisi kurang baik (negatif).

b. Nilai koefisien regresi variabel kompetensi yang positif $(1,539)$, berarti kompetensi berpengaruh positif terhadap kinerja auditor, sehingga peningkatan atau perbaikan pada variabel kompetensi akan meningkatkan kinerja auditor.

c. Nilai koefisien regresi variabel independensi yang positif $(1,326)$, berarti independensi berpengaruh positif terhadap kinerja, sehingga peningkatan atau perbaikan pada variabel independensi akan meningkatkan kinerja auditor.

d. Nilai koefisien regresi variabel etika yang positif $(22,859)$, berarti etika berpengaruh positif terhadap kinerja, sehingga peningkatan atau perbaikan pada variabel etika akan meningkatkan kinerja auditor.

e. Nilai koefisien regresi variabel interaksi kompetensi dengan etika yang negatif (0,033), berarti interaksi kompetensi dan etika berpengaruh negatif terhadap kinerja, sehingga peningkatan atau perbaikan pada variabel interaksi komptensi dengan etika akan mempengaruhi kinerja auditor.

f. Nilai koefisien regresi variabel interaksi independensi dengan etika yang negatif ($0,020)$, berarti interaksi independensi dan etika berpengaruh negatif terhadap kinerja, sehingga peningkatan atau perbaikan pada variabel interaksi independensi dengan etika akan mempengaruhi kinerja auditor.

Bila memperhatikan koefisien regresi di atas, maka pengaruh yang paling kecil dan terbesar secara urutan yaitu kompetensi, independensi dan etika. Dengan demikian variabel etika merupakan variabel yang paling besar pengaruhnya terhadap kinerja auditor. 
Berdasarkan nilai $F$ hitung untuk hasil regresi pertama (tabel 1) sebesar 15,891 , sedangkan $F$ tabel adalah 2,494 (dengan $\mathrm{dk}: \mathrm{n}-\mathrm{k}$ atau 40-6 = 34; pada taraf kesalahan 5 persen), sehingga $\mathrm{F}$ hitung $>\mathrm{F}$ tabel $(15,891>2,494)$, dengan signifikansi 0,000 lebih kecil dari alpha $(0,000<0,05)$, yang berarti variabel kompetensi, independensi, etika, interaksi variabel kompetensi dengan etika dan variabel interaksi independensi dengan etika secara bersama-sama berpengaruh terhadap kinerja auditor. Hasil regresi juga menampilkan koefisien determinasi yang digunakan untuk mengetahui sampai seberapa besar persentase variasi variabel bebas pada model dapat menerangkan variabel terikat (Gujarati, 2003). Koefisien determinasi dinyatakan dalam persentase, yaitu berkisar dari 0 - 1. Besarnya koefisien determinasi $\left(\mathrm{R}^{2}\right)$ dalam perhitungan regresi sebagaimana ditampilkan pada tabel sebelumnya adalah 0,700 atau 70 persen. Dapat diartikan bahwa 70 persen variasi variabel terikat yaitu kinerja pegawwai dapat diterangkan oleh variabel bebasnya yaitu kompetensi, independensi dan etika, sedangkan sisanya atau 30 persen dipengaruhi oleh variabel lain di luar model penelitian.

Pengujian hipotesis pertama dan ketiga dilakukan dengan mendasarkan pada hasil regresi linier berganda yaitu dengan uji t. untuk pengujian hipotesis kedua dan keempat didasarkan atas hasil uji moderasi. Pembahasan uji hipotessi dijelaksan di bawah ini:

\section{Hipotesis Pertama}

Berdasarkan nilai † hitung regresi untuk variabel kompetensi $\left(t_{1}\right)$ sebesar 2,335, sedangkan $\dagger$ tabel adalah 2,032 (dengan dk : n-k-1 atau $40-5-1=34$; pada taraf kesalahan 5 persen tabel 1, sehingga $\dagger$ hitung $>+$ tabel $(2,335>2,032)$, dengan signifikansi 0,026 Melihat hasil ini maka hipotesis pertama $\left(\mathrm{H}_{1}\right)$ yaitu kompetensi berpengaruh terhadap kinerja auditor intern pemerintah diterima. Hal ini menunjukkan bahwa variabel kompetensi auditor mempunyai pengaruh positif dan signifikan terhadap kinerja auditor. Artinya semakin baik kompetensi auditor maka akan meningkatkan kinerja auditor pemerintah.

Berdasarkan hasil regresi diketahui kompetensi auditor mempunyai pengaruh positif dan signifikan terhadap kinerja auditor. Hal ini menunjukkan bahwa semakin baik kompetensi auditor maka akan meningkatkan kinerja auditor. Bidang kerja auditor yang membutuhkan ketelitian dan kemampuan yang tinggi akan membutuhkan kesiapan auditor itu sendiri, karena modal kompetensi yang dimiliki akan membantu audtior dalam bekerja. Kharismatuti \& Hadiprajitno (2012) mengatakan auditor dengan pendidikan tinggi akan mempunyai pandangan yang lebih luas mengenai berbagai hal. Audior akan semakin mempunyai banyak pengetahuan mengenai bidang yang digelutinya, sehingga dapat mengetahui berbagai masalah secara lebih mendalam. Selain itu, dengan ilmu pengetahuan yang luas, 


\section{Uly Maria Ulfah}

\section{Fitri Lukiastuti}

auditor akan lebih mudah dalam mengikuti perkembangan yang semakin kompleks (Kharismatuti \& Hadiprajitno, 2012). Hasil penelitian ini mempunyai kesamaan dengan penelitian Sukriah et al. (2009) yang menemukan bahwa kompetensi berpengaruh positif terhadap kualitas hasil pemeriksaan (Sukriah et al., 2009). Penelitian Sujana (2012) pada kantor Inspektorat Kabupaten Badung dan Buleleng membuktikan bahwa kompetensi berpengaruh secara signifikan terhadap Kinerja. Hal ini menunjukkan bahwa semakin tinggi kompetensi auditor internal/pegawai inspektorat, semakin baik kinerja auditor internal/pegawai inspektorat dalam melaksanakan tugas (Sujana, 2012).

\section{Hipotesis Kedua}

Berdasarkan nilai $\dagger$ hitung regresi untuk variabel interaksi kompetensi dengan etika $\left(\dagger_{4}\right)$ sebesar -2,671, sedangkan † tabel adalah 2,032 (dengan $\mathrm{dk}: \mathrm{n}-\mathrm{k}-1$ atau $40-5-1$ = 34; pada taraf kesalahan 5 persen - lampiran 10), sehingga t hitung > t tabel $(-2,671<-2,032)$, dengan signifikansi 0,012 . Berdasarkan hasil analisa variabel kompetensi ( $b_{1}$ ) dan moderator yaitu interaksi antara variabel kompetensi dengan etika $\left(b_{4}\right)$ menunjukkan hasil yang sama-sama signifikan. Hal ini menunjukkan bahwa variabel etika adalah variabel quasi moderator atau dapat digunakan sebagai variabel independen sekaligus variabel moderator. Melihat hasil ini, hipotesis kedua $\left(\mathrm{H}_{2}\right)$ yaitu moderasi kompetensi dan etika auditor berpengaruh terhadap kinerja auditor intern pemerintah diterima, sehingga variabel etika auditor mampu memoderasi pengaruh kompetensi dengan kinerja auditor pemerintah.

Berdasarkan hasil analisa moderasi, diketahui etika auditor merupakan variabel quasi moderator antara kompetensi audtior terhadap kinerja auditor. Dengan kata lain dukungan etika yang dimiliki auditor akan membantu atau mendukung kompetensi yang dimilikinya sehingga akan mengembangkan kinerja yang ada selama ini. Herhinto (2004) menjelaskan bahwa jika auditor memperhatikan etika dalam interaksi kompetensi akan menghasilkan kinerja yang baik (Herhinto, 2004). Hasil penelitian ini mendukung penelitian sebelumnya yang telah dilakukan oleh Saputra (2013), yang menunjukkan bahwa etika auditor dapat memoderasi pengaruh kompetensi terhadap kualitas audit. Hasil pengujian model regresi menghasilkan interaksi kompetensi dan etika auditor yang memiliki pengaruh positif. Karenaanya perbaikan kinerja auditor memerlukan dukungan kompetensi dan etika auditor (Saputra, 2013).

\section{Hipotesis Ketiga}

Berdasarkan nilai t hitung regresi untuk variabel independensi $\left(t_{2}\right)$ sebesar 2,430 , sedangkan $\dagger$ tabel adalah 2,032 (dengan dk : n-k-1 atau 40- 5 - 1 = 34; pada taraf kesalahan 5 persen tabel 1$)$, sehingga $\dagger$ hitung $>$ t tabel $(2,430>2,032)$, dengan signifikansi 0,021 . Melihat hasil ini 
maka hipotesis ketiga $\left(\mathrm{H}_{3}\right)$ yaitu independensi berpengaruh terhadap kinerja auditor intern pemerintah diterima. Hal tersebut menunjukkan bahwa variabel independensi auditor mempunyai pengaruh positif dan signifikan terhadap kinerja auditor. Hal ini juga memiliki arti bahwa semakin baik independensi auditor, dapat meningkatkan kinerja auditor pemerintah. Hasil regresi menunjukkan bahwa variabel independensi auditor mempunyai pengaruh positif dan signifikan terhadap kinerja auditor, yang artinya semakin baik independensi auditor maka akan meningkatkan kinerja auditor. Hal ini juga akan mempengaruhi tingkat pencapaian pelaksanaan suatu pekerjaan yang semakin baik atau dengan kata lain kinerjanya akan menjadi lebih baik (Gustia, 2014). Dengan memberi penilaian yang senyatanya terhadap laporan keuangan yang diperiksa, maka penilaiannya akan mencerminkan kondisi perusahaan yang sebenarnya, sehingga auditor dapat dipercaya oleh semua pihak yang berkepentingan. Hasil penelitian ini memunyai kesamaan dengan penelitian sebelumnya yang telah dilakukan oleh Nini \& Trisnawati (2009) yaitu hasil penelitiannya menunjukkan bahwa independensi, berpengaruh signifikan positif terhadap kualitas pemeriksaan Inspektorat Kabupaten Konawe Kota Kendari dan Kabupaten Kolaka.

\section{Hipotesis Keempat}

Berdasarkan nilai t hitung regresi untuk variabel interaksi independensi dengan etika ( $t_{5}$ ) sebesar -2,141, sedangkan $t$ tabel adalah 2,032 (dengan $d k: n-k-1$ atau $40-5-1=34$; pada taraf kesalahan 5 persen - lampiran 10), sehingga t hitung > t tabel $(-2,141<-2,032)$, dengan signifikansi 0,040 . Berdasarkan hasil analisa variabel independensi $\left(b_{2}\right)$ dan moderator yaitu interaksi antara variabel independensi dengan etika ( $\left.b_{4}\right)$ sama-sama signifikan. Hal ini menunjukkan bahwa variabel etika adalah variabel quasi moderator atau dapat digunakan sebagai variabel independen sekaligus variabel moderator. Melihat hasil ini maka hipotesis keempat $\left(\mathrm{H}_{4}\right)$ yaitu moderasi independensi dan etika auditor berpengaruh terhadap kinerja auditor intern pemerintah diterima, sehingga variabel etika auditor mampu memoderasi pengaruh independensi dengan kinerja auditor pemerintah.

Berdasarkan hasil analisa moderasi, diketahui etika auditor merupakan variabel quasi moderator antara independensi audtior terhadap kinerja auditor. Hal ini juga menunjukkan bahwa dukungan etika yang dimiliki auditor akan membantu atau mendukung independensi yang dimilikinya sehingga akan mengembangkan kinerja yang ada selama ini. Saat ini kemampuan auditor untuk dapat bertahan di bawah tekanan klien mereka tergantung dari kesepakatan ekonomi, lingkungan tertentu, dan perilaku termasuk di dalamnya mencakup etika profesional, karena itulah upaya menjaga etika dan di sisi lain berupaya independen akan memberikan hasil kerja yang obyektif. Hasil penelitian ini mendukung kajian sebelumnya yang telah dilakukan oleh Saputra (2013) bahwa etika 


\section{Uly Maria Ulfah}

\section{Fitri Lukiastuti}

auditor dapat memoderasi pengaruh indenpendensi terhadap kualitas audit. Hal ini berarti bahwa etika audit yang dilakukan dengan baik oleh auditor akan meningkatkan pengaruh indenpendensi terhadap kualitas audit (Saputra, 2013).

\section{SIMPULAN}

Kompetensi auditor memberikan dampak bagi peningkatan kinerja auditor pemerintah. Hal ini sesuai hasil regresi yang membuktikan kompetensi auditor berpengaruh positif dan signifikan terhadap kinerja auditor pemeirntah, dengan nilai signifikansi 0,026 . Hasil ini dapat diartikan bahwa perbaikan kompetensi auditor akan mampu meningkatkan kinerja auditor pemerintah.

Hasil regresi membuktikan variabel kompetensi auditor signifikan mempengaruhi kinerja auditor dan interaksi antara variabel kompetensi dengan etika juga signifikan berpengaruh terhadap kinerja audtor dnegan signifikansi 0,012. Hasil ini dapat diartikan variabel etika menjadi quasi moderator atau dapat digunakan sebagai variabel independen sekaligus variabel moderator, dengan kata lain etika auditor mampu memoderasi pengaruh kompetensi dengan kinerja auditor pemerintah.

Independensi auditor memberikan dampak bagi peningkatan kinerja auditor pemerintah, hal ini sesuai hasil regresi yang membuktikan independensi auditor berpengaruh positif dan signifikan terhadap kinerja auditor pemeirntah, dengan nilai signifikansi 0,021. Hasil ini dapat diartikan bahwa perbaikan independensi auditor akan mampu meningkatkan kinerja auditor pemerintah.

Hasil regresi membuktikan variabel independensi auditor signifikan mempengaruhi kinerja auditor dan interaksi antara variabel independensi dengan etika juga signifikan berpengaruh terhadap kinerja audtor dengan signifikansi 0,040. Hasil ini dapat diartikan variabel etika menjadi quasi moderator atau dapat digunakan sebagai variabel independen sekaligus variabel moderator, dengan kata lain etika auditor mampu memoderasi pengaruh independensi denngan kinerja auditor pemerintah. 


\section{DAFTAR PUSTAKA}

Ghozali, I., 2006, Aplikasi Analisis Multivariate dengan Program SPSS, Badan penerbit Undip Semarang, Semarang.

Gujarati, D. 2003. Ekonomimetrika Dasar, Jakarta: Erlangga.

Nila, G. 2014. Pengaruh Independensi Auditor, Etika Profesi, Komitmen Organisasi, Dan Gaya Kepemimpinan Terhadap Kinerja AUDITOR PEMERINTAH (Studi Empiris pada Auditor Pemerintah di BPKP Perwakilan Sumbar), Jurnal Akuntansi Vol 2 No 3. Surabaya.

Teguh, H. 2004, Pengaruh Keahlian dan Indepensi terhadap kalitas Adit" Study Empiris pada KAP Jawa Timur,Tesis Maksi: Universitas Diponegoro.

Kharismatuti, N., and Hadiprajitno. B. 2012. "Pengaruh Kompetensi dan Independensi terhadap Kualitas Audit dengan Etika Auditor sebagai Variabel Moderasi" (Studi Empiris pada Internal Auditor BPKP DKI Jakarta). Diponegoro Journal of Accounting Vol.1 No.1 Hal 1-10.

Nini and Estralita T. 2009. Pengaruh Independensi Auditor pada KAP Big Four terhadap Manajemen Laba Pada Industri Bahan Dasar Kimia dan Industri Barang Konsumsi. Jurnal Bisnis dan Akuntansi, Vol 11/NO.3 : hlm 175-188.

Salju, Rismawati dan Muhammad Dirga Bachtiar, 2014, Pengaruh Kompetensi dan Independensi Terhadap Kinerja Auditor Pemerintah Kabupaten Luwu Timur Jurnal Equilibrium Vol. 04 No. 02.

Sugiyono. 2014. Metode Penelitian Kuantitatif, Kualitatif, dan Kombinasi (Mixed Methods). Bandung : Alfabeta.

Sujana, E., 2012. Pengaruh Kompetensi, Motivasi, Kesesuaian Peran Dan Komitmen Organisasi Terhadap Kinerja Auditor Internal Inspektorat Pemerintah Kabupaten (Studi Pada Kantor Inspektorat Kabupaten Badung Dan Buleleng), Jurnal IImiah Akuntansi dan Humanika, Volume 2 Nomor 1 Singaraja ISSN 2089-3310.

Saputra. and Anton E,. 2013. Pengaruh Kompetensi Dan Independensi Terhadap Kualitas Audit Dengan Etika Auditor Sebagai Variabel Moderasi (Studi Empiris Pada Auditor di 


\section{Uly Maria Ulfah}

\section{Fitri Lukiastuti}

Kantor Akuntan Publik se-Jawa Tengah dan D.I Yogyakarta). JURAKSI. Vol. 1 No. 2 Februari 2012. ISSN: 2301-9328.

Sukriah, I., Akram, and Biana A. 2009. Pengaruh Pengalaman Kerja, Independensi, Obyektifitas, Integritas, dan Kompetensi terhadap Kualitas Hasil Pemeriksaan. Paper Dipresentasikan di Simposium Nasional Akuntansi XII, Palembang.

Ratna W., I Ketut Y., and Astika, I 2017, Komitmen Organisasi Sebagai Pemoderasi Pengaruh Motivasi, Kepuasan Kerja, Dan Kompetensi Pada Kinerja Auditor (Studi Empiris Pada Kantor Akuntan Publik Di Bali), E-Jurnal Ekonomi dan Bisnis Universitas Udayana 6.1 (2017): 329-356, ISSN : 2337-3067. 